\title{
LEARNING THEORY
}

\author{
Muthmainnah \\ Universitas Al Asyariah Mandar, Indonesia
}

Nenni Dwi Aprianti Lubis

Universitas Sumatera Utara, Indonesia

Article Info

Keywords

Learning theories, cognitivism,

behavior, observational learning, teacher.

\begin{abstract}
Learning is a dynamic process in which information and experience can be transformed into knowledge, abilities, actions and attitudes. Different theories of learning help us understand how we learn. Many teaching methods have also shown that they have been effective. We must also take into account the many different teaching roles and their importance; each role server as a means of learning is created. Some teachers (expert, formal instructor, authority, facilitator and delegator of the personal model), while other teachers rely on the same techniques that are proven and checked. However, adapting teaching methods to accommodate the situation and invidual needs are part of a most effective method of teaching. It has demonstrated the significance of teaching behavior and the different teaching methods and the forecast benefits of student learning.
\end{abstract}

\section{INTRODUCTION}

The theory of learning explains the ways in which students obtain, process and preserve information. Cognitive, emotional and environmental impacts and past interactions all lead to the acquisition or transformation of the perception or view of the world and the retention of information and skills.

Behavioralist view schooling as a training element and promote a system of education incentives and goals. Educators who support cognitive science claim that learning as a behavior change is too restrictive to be described and research the learner rather than his or her environment, particularly his or her complex memory. Many who support construction claim that the capacity of a learner to learn depends largely on what he already knows and understands and that knowledge acquisition should be a personalized construction process. Transforming learning theory focuses on the often needed changes in the preconceptions and world view of a learner. Geographical theory concentrates on how contexts and environments form the process of learning.

We continue to do our whole lives, learning is something. It's a dynamic process by which awareness, abilities, habits and attitudes can be translated into information and experience. In everything, and maybe to various degrees, there is the opportunity to learn. We must research the various theories and philosophies in order to fully understand the complexity of learning.

Learning can be defined as a process that combines both cognition, emotion and the environment in order to learn or improve information, values, skills and world views Illeris (2000); (1995). The learning process focuses on what happens during the learning process. Tighe (1982) has shown that learning can be differentiated from behavioral changes induced by maturation and disease; it does also apply to engine skills, such as cycling, analytical ability, writing, some attitudes and beliefs, such as A suggested by Wolfe (1952) that neurotic symptoms and mental disorder patterns can also be learned. Illeris (2000, p-3) narrowly describes learning as "any process that in living organisms leads to permanent capacity change and which is not solely due to biological maturation or aging." A learning theory is applied to explain the dynamic mechanisms involved in learning, how adults and children learn.

Learning theories are an ordered collection of principles that describe how people learn, conserve and remember information. We can better understand how learning takes place through research and by understanding the various learning theories. The criteria for the selection of educational materials, techniques and methods to facilitate learning can be utilized in the concepts of theories. 
1. Behaviorism

2. Cognitivism

3. Constructivism

A. Behaviorism

Comportement was born in the late 19th and early 20th centuries from research performed by Ivan Pavlov. The study carried out by Pavlov on animal digestion culminated in the recognition that the animals examined were to salive, regardless of whether food was being treated by the laboratory worker assigned to feed them. Pavlov realized that the laboratory assistant had started to be correlated with food, and that the unconditional reaction to unconditional stimuli salivating while food was in the laboratory was replaced by a conditioned response. In addition, the initial trigging stimuli (laboratory assistant) were replaced by a new stimulus (the ringing of the bell) in order to achieve the reaction. He then trained the animals to unlearn the learned reaction to stimulus so that when a bell was banged the dogs could no longer salivate. Classical conditioning is known as this method of linking neutral stimuli in order to obtain conditions. John Watson has built on Pavlov's studies and applied the theory of conditioning to the development and teaching of men to "learn how to combine an unconditionally motivated stimulus which already leads to a certain response(reflex) with a new stimulus (conditional)." Learning is seen by action in behavioralism and must be observed and expressed in the actions. Essentially, behavioral behavioralism is focused on cause, effectiveness and the correct combination of recompense and punishments are used to motivate and mold conduct. Further research explored the role of voluntary action, for example the deliberate execution of an act. These studies have shown that increased awards have contributed to a repeat of the probability of the action.

The use of incentives and sanctions as trainers and instructors can be matched for performance. This involves the use for training purposes of beneficial or unnecessary behaviors. For example, it has been proven that social recognition and gratitude from gold stars to awards strengthen the probability of repeated desired action. Likewise, the desired behaviors, such as the allocation of time for leisure or the desired tasks, can contribute to habitual behaviours. Disincentives can, by comparison, be used to restrict the repetition of unwanted behaviors and to direct the participants towards their desired acts.

Conduct is most successful if the new experience or capacity has only one right answer or way to be done or in practices in which differences in thinking and implementations are minimised. Only one correct answer should be given. Behavior may also be successful in the area of social education and rule-making, with incentives for enforcement. To be most successful, at the beginning of the training session, participants should be aware of the rules, and the instructor should explain the anticipated performance level.

\begin{tabular}{|l|l|}
\hline \multicolumn{2}{|c|}{ Behaviorism } \\
\hline \multicolumn{1}{|c|}{ Pros } & \multicolumn{1}{c|}{ Cons } \\
\hline Helps the instructor set high expectation & May be immorally applied and used \\
\hline $\begin{array}{l}\text { Good for establishing rules and expected } \\
\text { norms of behavior }\end{array}$ & $\begin{array}{l}\text { May not address the core of behavioral issues, } \\
\text { such as outside personal issues }\end{array}$ \\
\hline $\begin{array}{l}\text { Participants should be familiar with the } \\
\text { reward system }\end{array}$ & $\begin{array}{l}\text { Does not look at nonobservable learning (e.g., } \\
\text { affective domain) }\end{array}$ \\
\hline Simple to use & Does not take emotions into account \\
\hline & $\begin{array}{l}\text { Does not work for high cognition or complex } \\
\text { thought }\end{array}$ \\
\hline
\end{tabular}

\begin{tabular}{|c|c|}
\hline \multicolumn{2}{|c|}{ Reinforcement Table (what is the most effective reinforcement schedule) } \\
\hline Reinforcement Schedule & Likelihood of Repetition \\
\hline Continuous (reinforce after every occurrence) & Low to moderate \\
\hline Fixed ratio (e.g., 4 to 1 ) & Low to moderate \\
\hline Intermittent or random & Moderate to high \\
\hline
\end{tabular}

\begin{tabular}{|ll|}
\hline & Behaviorism Terms \\
Stimulus & Anything that affects behavior \\
Response & Behavior in response to the stimulus \\
Unconditioned stimulus & Feature that causes a natural, reflex action \\
Conditioned stimulus & Feature that has an affect through association with use \\
Extinction & Dying out of a conditioned reflex \\
Spontaneous recovery & Return of a conditioned response \\
Generalization & Similar stimuli to conditioned stimuli that gets a \\
& response \\
Discrimination & The ability to tell the difference between two similar \\
& stimuli (the opposite of generalization) \\
\hline
\end{tabular}




\section{B. Cognitivism}

Although learning with mental activity was defined by both cognitivism and constructivism, constructivism varies in different ways from cognitiveism. Again in Jonnassen's words (1991b), "Mast cognitive psychologists think of the mind as a tool to reference the real world; constructivists believe that the mind filters the insights into the world to produce its own uniquely uniquely real reality."

"The Constructors don't deny the existence of the real world. They claim that the world we know is derived from our own interpretations of our experience." Eritmer and Newby (2013) offers us a great description of what constructivists think. In comparison to it, humans build meaning. As there are several meanings to glean from interactions, a predefined, "correct" interpretation cannot be achieved. Learners don't transfer information from the outside world to their memories; they instead create the world's own personal understandings based on individual experiences and interactions. There is, therefore, a continually shifting inner reflection of knowledge; there's no objective truth that students aspire to learn».

This learning theory is rooted in Jean Piaget's work, which notes that learning takes place internally by information processing instead of simply through reacting to an external stimulus. Learning is the product of information collection and reorganization within a matrix of information previously collected. Cognitivism focuses on the thought processes of the person and the instructor emphasizes the meditation on metacognition experiences, thinks about their thinking. This behavioral improvement is a result of learning after the internal working of thought based on the new knowledge or information gained. The learning process involves both learning and cognitive entity reorganization.

Cognitivism applied to behavioral theories by looking at students not as blank panels but as people with specific viewpoints, perspectives and know-how and teachers to meet the participants' learning needs. The appreciation of subjective intelligence vision of students means that lessons and exercises may have different results depending on the experience of learners. In addition to the newly gained knowledge and talents, students often strive to evolve a working model of the environment and how this works.

Although the teacher is regarded as the expert who imparts expertise to unknown students in the classroom of behavior, cognitive instructors seek to guide students through an area of development, bridging the participants with what they are not familiar with. Teachers aim to help students incorporate new skills and knowledge into their academic structure and adjust their views of the world as appropriate. Teachers apply cognitive skills to help students refine their reasoning. They ask questions. Teachers may also use games, jigsaw puzzles, flash cards and other means to generate imbalance that the student needs to adapt and proceed.

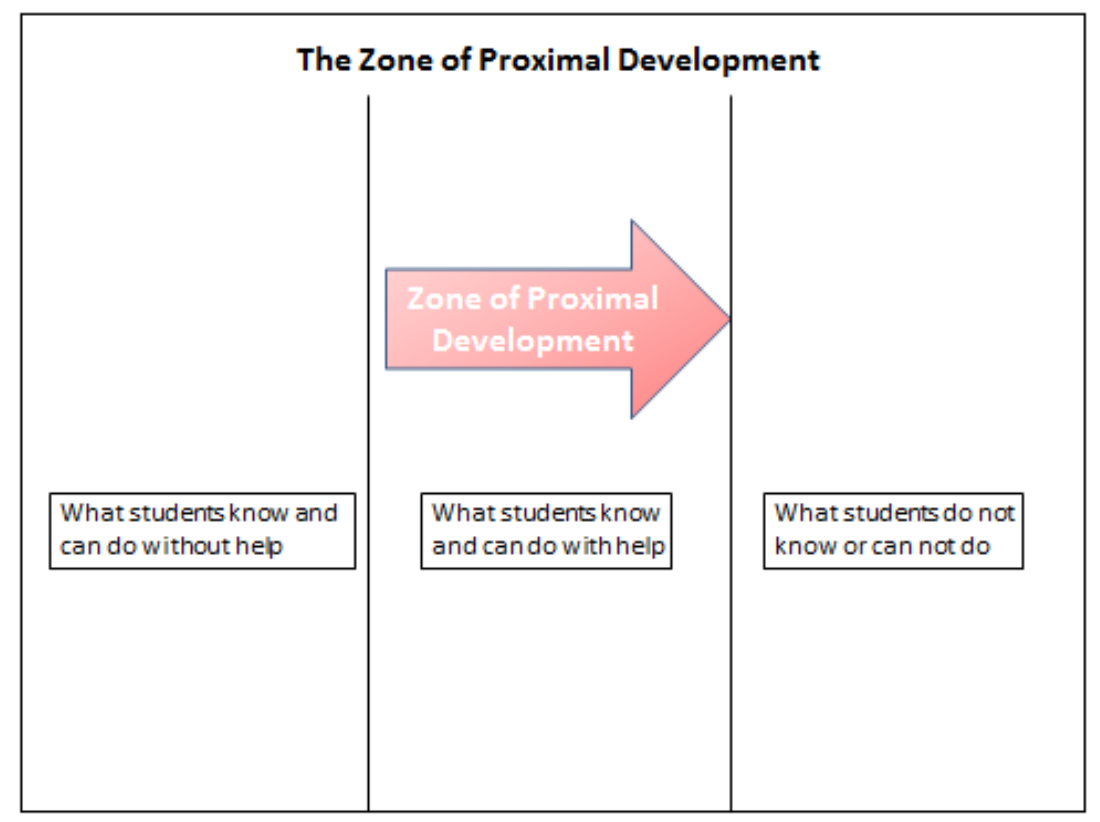

\section{Constructivist and Connectivism}


The concept that learners actively construct their own knowledge, is based on their own significance and is guided by previous knowledge and events is based on Constructivist Learning Theory. New knowledge and knowledge modify the known, and learning occurs when it is used to solve problems, tests and/or applications. In short, information can be received without application, but there is no understanding. Furthermore, learning is a social activity involving sharing and use through the proximal development area.

Connectivism adds to constructivism to explain how the internet created information and allowed it to be shared worldwide. Info and knowledge will no longer be stored in the single or small group, but worldwide. Instructors focus on providing the context, interpretation and assessment of stored knowledge. Learning is no longer an educational activity via connectivism and the role of peer networks in the conservation, interpretation and application of information is even greater. Knowledge and authority are shared in the classroom with instructors who lead the learners to learn and apply knowledge in heterogeneous groups. The instructor's role is to create a collaborative and problematic environment and to provide insights, insights and activities that adapt to the student's needs. Building Teaching Comportements (Brooks and Brooks, 1993)

1. Encourage and accept student autonomy and initiative.

2. Use raw data and primary sources, along with manipulative, interactive, and physical materials.

3. When framing tasks, use cognitive terminology, such as "classify, analyze, predict, and create."

4. Allow student responses to drive lessons, shift instructor strategies, and alter content.

5. Inquire about students' understanding of the concepts before sharing (your) own understanding of those concepts.

6. Encourage students to engage in dialogue, both with the teacher and with one another.

7. Encourage student inquiry by asking thoughtful, open-ended questions, and encourage students to ask questions of each other.

8. Seek elaboration of students' initial responses.

9. Engage students in experiences that might engender contradictions to their initial hypothesis and then encourage discussion.

10. Allow wait time after posing questions.

11. Provide time for students to construct relationships and create metaphors.

12. Nurture students' natural curiosity through frequent use of the learning cycle model.

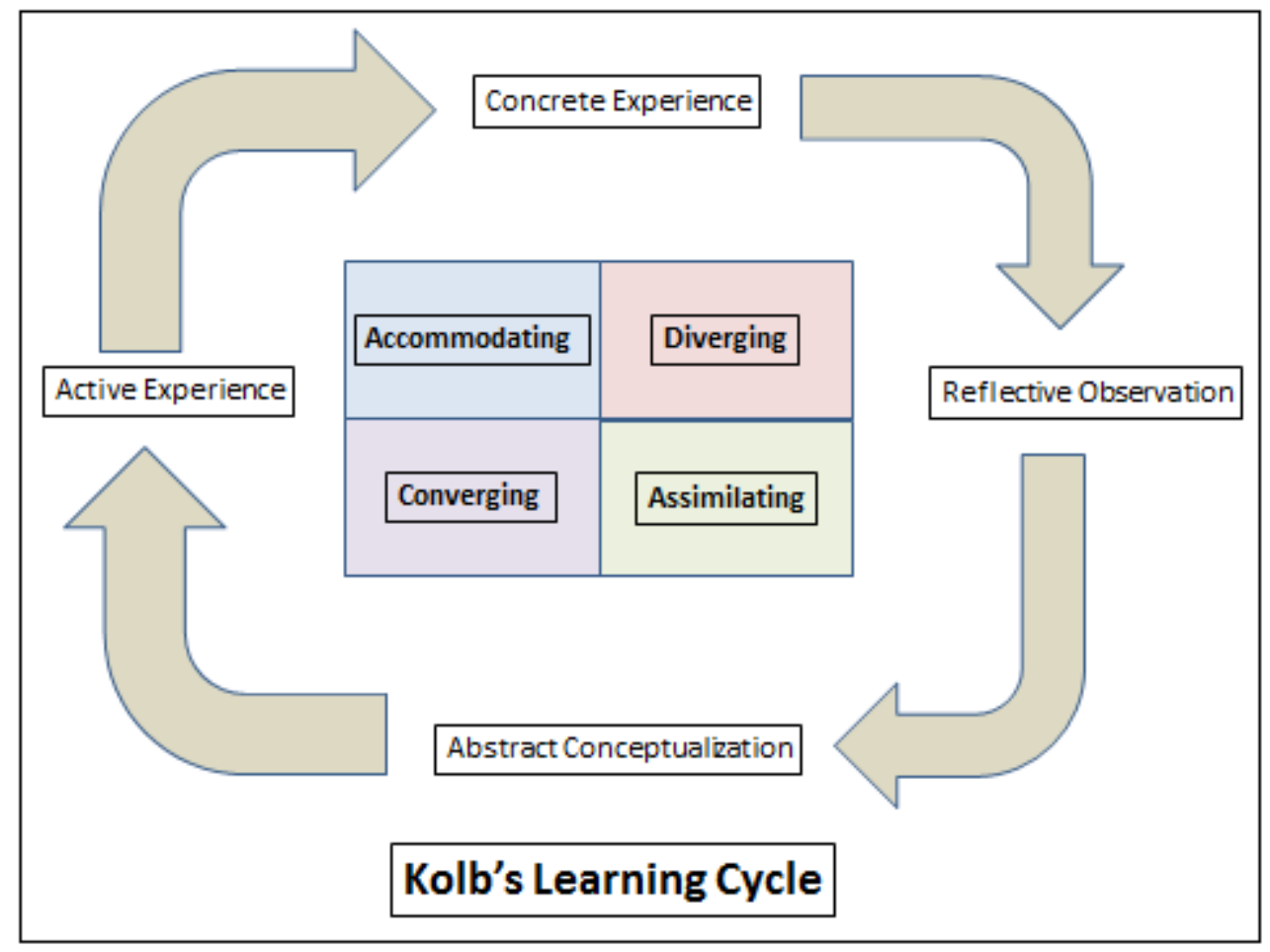

Goals of the Constructivist Classroom

1. Students determine how they will learn.

2. Evaluation of alternative solutions.

3. Realistic tasks are embedded in the learning. 
4. Student-centered.

5. Collaboration is valued.

6. Multiple modes of instruction are used.

7. Encourage awareness of the knowledge contraction process (reflection, metacognition).

Understanding basic learning theory allows the instructor to develop and present course materials in a manner that best meets the needs of the learner. Based on learner development, capabilities, experiences, and life stage, instructors may use different learning theories to share knowledge and improve learner abilities. Remembering that adult learners have different learning needs and may have had different learning models used during their development, instructors should be fluent in the theories and able to shift between models based on the needs of the learner to fully meet the learning objectives.

\begin{tabular}{|l|l|}
\hline \multicolumn{2}{|c|}{ The Classroom } \\
\hline \multicolumn{1}{|c|}{ Behaviorist } & \multicolumn{1}{c|}{ Constructivist } \\
\hline Fixed curricula & Based on student questions and interest \\
\hline Repetition & Interactive and built on student KSAs \\
\hline Teacher centered & Learner centered \\
\hline Passive & Active \\
\hline Monologue & Dialogue \\
\hline Individual work & Group work \\
\hline
\end{tabular}

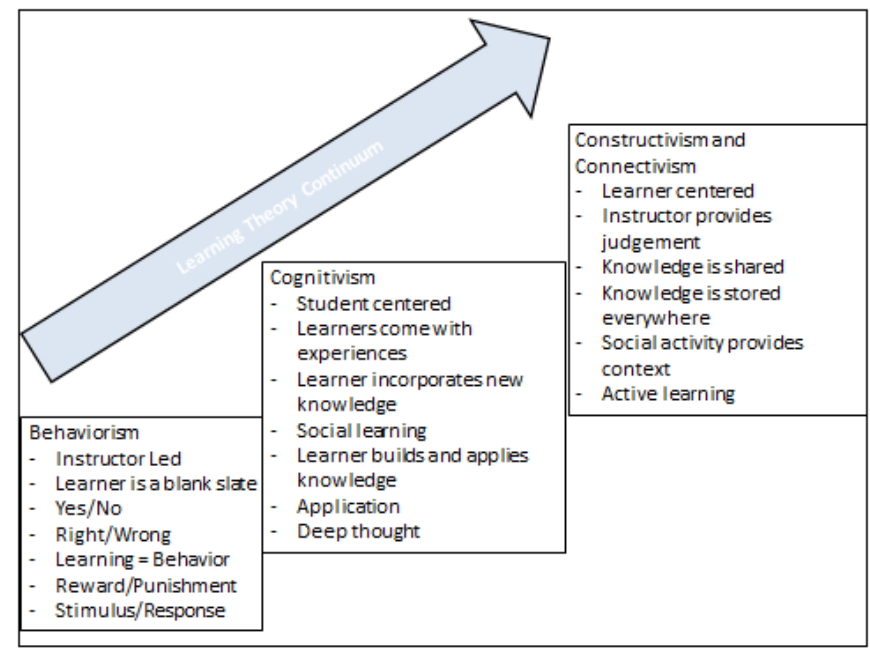

\section{CONCLUSION}

Learning is a complex process through which knowledge and experience can be converted into knowledge, skills, attitudes and behaviours. The broad definition of Illeris (2000) is that learning is any "any process that in living organisms leads to permanent capacity change and which is not solely due to biological maturation or aging." There are also many teaching methods which prove to be successful. It is also essential to note a teacher's many different roles and their significance; each role is a means to achieve learning results. Various teachers have various teaching styles and are constantly following the same techniques; however, changing the teaching style to suit individual needs and circumstances is the most successful method of teaching. It has been demonstrated the importance of teaching and of the different styles of teaching and the predicted benefits in student learning.

\section{REFERENCES}

Flippen, C. (2019). Cognitivism. Retrieved from https://edtechtheory.weebly.com/cognitivism.html.

Krist. (2015). Connectivism (Siemens, Downes). Learning Theories. www.learning-theories.com/connectivism-SiemensDownes.html.

The Peak Performance Center. (n.d.) Learning Cycle. https://thepeakperformancecenter.com/educationallearning/learning/process/learning-cycle/.

Brooks, J. \& Brooks, M. (1993). In search of understanding: the case for constructivist classrooms. ASCD. NDT Resource Center Data Base.

McLeod, D. (2019). Constructivism: as a theory for teaching and learning. https://www.simplypsychology.org/constructivism.html.

Drew, C. (2020). Behaviorism-Skinners education learning theory (2020). https://helpfulprofessor.com/behaviorism/\#: text=Pros\%20and\%cons\%20behaviorism\%20in\%20education.

McLeod, S. (2013). Pavlov's dogs. www.simplypsychology.org/pavlov.html. 
Ertmer, P.A. \& Newby, T.J. (2013). Behaviorism, Cognitivism, Constructivism: Comparing Critical Features From an Instructional Design Perspective. Performance Improvenment Quaterly. Volume 26. International Society for Performance Improvement Published online in Wiley Online Library. p. 55.

Jonassen, D.H. (1991). Objectivism vs constructivism: Do we need a new philosophical paradigm. Educational Technology Research and Development.Volume 39. Washington, D.C. USA.

Jonassen, D.H. (1991b). Evaluating constructivistic learning. Educational Technology. Volume 31.

Snelbecker, G.E. (1983). Learning theory, instructional theory, and psychoeducational design. McGraw-Hill. New York.

Asrifan, A. (2009). Using songs in teaching English language for the young learners. ParePare: unpublished.

Puasa, K., Asrifan, A., \& Chen, Y. (2017). Classroom Talk in Bilingual Class Interaction. Research in Pedagogy, 7(1), 106121.

Nadirah, N., Tahir, M. H., \& Asrifan, A. (2019). THE ABILITY TO TRANSLATE ENGLISH PHRASES INTO INDONESIAN AND THE DIFFICULTIES FACED BY THE ELEVENTH GRADE STUDENTS OF SMAN 1 PANCARIJANG. JOURNAL OF ADVANCED ENGLISH STUDIES, 2(1), 41-46.

Apdy, A. P. R., \& Asrifan, A. (2019, April). The Chinese mime game in teaching vocabulary on EFL classroom. In PROCEEDINGS OF THE 65th TEFLIN INTERNATIONAL CONFERENCE (Vol. 65, No. 01).

Taslim, T., Asrifan, A., Chen, Y., \& Nurdania, N. R. (2019). CORRELATION BETWEEN STUDENT'S VOCABULARY MASTERY AND SPEAKING SKILL. JOURNAL OF ADVANCED ENGLISH STUDIES, 2(2), 65-76.

Muthmainnah, M., Asrifan, A., Al Yakin, A., \& Sahabuddin, C. (2019, April). The use of dictogloss technique on ELT classroom: An experiment study of students listening comprehension. In PROCEEDINGS OF THE 65th TEFLIN INTERNATIONAL CONFERENCE (Vol. 65, No. 01).

Mutmainnah, M., Azis, S., Maulidya, U., \& Asrifan, A. (2017). Glory Style in Mandar Song Lyrics: A study of Mandar Tribe in South Sulawesi, Indonesia. JOURNAL OF ADVANCES IN LINGUISTICS, 8(1), 1286-1291.

Asrifan, A., Rinantanti, Y., Tang, S., \& Nadirah, N. (2019). THE 3-DIMENSION PICTURES IN INCREASING THE STUDENTS ABILITY AND INTEREST TO WRITE DESCRIPTIVE COMPOSITION. JOURNAL OF ADVANCED ENGLISH STUDIES, 2(1), 19-30

Asrifan, A., Nadira, N., \& Haedar, H. (2018). IMPROVING STUDENTS'READING COMPREHENSION OF DESCRIPTIVE TEXT THROUGH COLLABORATIVE MURDER. JOURNAL OF ADVANCED ENGLISH STUDIES, 1(2), 21-31.

Asrifan, A. (2015). Analysis of English Students' Learning Style in Bilingual Class. International Journal of Literature and Arts, 3(4), 34.

Farahdiba, S., \& Asrifan, A. (2016). Speaking Ability and Psychological Barriers of the Second Year Students of Hotel Department of SMKN 1 Sidenreng Kabupaten Sidrap in Speaking English. Asian EFL Journal, (89), 41.

Asrifan, A. (2012). Increasing the Students Ability to Write Descriptive Composition at SMP Negeri 13 Parepare by using the 3-Dimension Pictures.

Tang, S., Asrifan, A., Chen, Y., Haedar, H., \& Agussalim, M. (2019). THE HUMOR STORY IN TEACHING READING COMPREHENSION. JOURNAL OF ADVANCED ENGLISH STUDIES, 2(2), 77-87.

Nurwanti, N., Asrifan, A., \& Haedar, H. (2019). THE APPLICATION OF COOPERATIVE LEARNING: JIGSAW II TECHNIQUE IN IMPROVING STUDENTS'READING COMPREHENSION OF EXPOSITORY TEXT. JOURNAL OF ADVANCED ENGLISH STUDIES, 2(1), 31-40.

Asrifan, A. (2016). The Effectiveness of Think-Pair-Share Technique in Improving Studentsâ€тм Speaking Ability and Interest. English Literature and Language Review, 2(3), 24-35.

Asrifan, A., Muthmainnah, M., Al-Yakin, A., Sahabuddin, C., \& Haedar, H. (2018). THE CAUSE-EFFECT TECHNIQUE IN TEACHING RECOUNT WRITING. JOURNAL OF ADVANCED ENGLISH STUDIES, 1(2), 63-72.

Asrifan, A., Vargheese, K. J., Syamsu, T., \& Amir, M. (2020). ESP COURSE DESIGN: THE NEED ANALYSIS ON TOURISM DEPARTMENT IN INDONESIA VOCATIONAL HIGH SCHOOLS. JOURNAL OF ADVANCED ENGLISH STUDIES, 3(2), 69-77.

Asrifan, A., Ghofur, A., \& Azizah, N. (2020). Cheating Behavior in EFL Classroom (A Case Study at Elementary School in Sidenreng Rappang Regency). OKARA: Jurnal Bahasa dan Sastra, 14(2), 279-297.

Nadirah, N., Asrifan, A., Vargheese, K. J., \& Haedar, H. (2020). INTERACTIVE MULTIMEDIA IN EFL CLASSROOM: A STUDY OF TEACHING READING COMPREHENSION AT JUNIOR HIGH SCHOOL IN INDONESIA. JOURNAL OF ADVANCED ENGLISH STUDIES, 3(2), 131-145.

Muthmainnah, A. R., Atmowardoyo, H., Salija, K., \& Asrifan, A. (2020). Literary Work as Teaching Materials: A Study of Students and Lecturers Needs Analysis. Solid State Technology, 63(5), 394-407.

Tilome, A. A., Agustang, A., Jasruddin, M. S., \& Asrifan, A. (2020). Social Exchange of Political Elites in the Regional Leader Election of Gorontalo Province, Indonesia. Solid State Technology, 63(5), 521-531.

Pacinongi, A., \& Asrifan, A. (2020). Bimbingan Pengawas Berkelanjutan dalam Mewujudkan Pendidikan Karakter Bangsa dalam Kegiatan Belajar Mengajar Penjaskes. Celebes Education Review, 2(1), 1-7.

Gunawan, G., \& Asrifan, A. (2020). Penerapan Kerja Kelompok Kegiatan MGMP Guru Ekonomi dalam Menyusun RPP untuk Meningkatkan Kompetensi Pedagogik. Celebes Education Review, 2(1), 31-36.

Yusuf, I., \& Asrifan, A. PENINGKATAN AKTIVITAS KOLABORASI PEMBELAJARAN FISIKA MELALUI PENDEKATAN STEM DENGAN PURWARUPA PADA SISWA KELAS XI IPA SMAN 5 YOGYAKARTA. Editorial Team, 32.

Al Yakin, A., Sahabuddin, C., Rahayu, A., Fitrah, N., \& Arifin, M. (2020). Political Celebrification and Electability: A Study of Political Phenomena Imaging in Election Polewali Mandar District, West Sulawesi, Indonesia. Solid State Technology, 63(5), 632-646.

Junaedah, S. B. T., \& Ahmad, M. A. (2020). The Outdoor Learning Modules Based on Traditional Games in Improving Prosocial Behaviour of Early Childhood. International Education Studies, 13(10). 
Octaberlina, L. R., \& Muslimin, A. I. (2020). Efl students perspective towards online learning barriers and alternatives using moodle/google classroom during covid-19 pandemic. International Journal of Higher Education, 9(6), 1-9.

Octaberlina, L. R., \& Anggarini, I. F. (2020). Teaching vocabulary through picture cards in Islamic Elementary School: a case study in Nida Suksa School, Thailand. Jurnal Madrasah, 13(1), 26-38.

Octaberlina, L. R. (2016). Plagiarism in English language theses in Indonesia. Jurnal Ilmu Pendidikan, 14(3).

Octaberlina, L. R., \& Anggarini, I. F. (2020). Teaching vocabulary through picture cards in Islamic Elementary School: a case study in Nida Suksa School, Thailand. Jurnal Madrasah, 13(1), 26-38.

Asrifan, A., Zita, C. T., Vargheese, K. J., Syamsu, T., \& Amir, M. (2020). THE EFFECTS OF CALL (COMPUTER ASSISTED LANGUAGE LEARNING) TOWARD THE STUDENTS'ENGLISH ACHIEVEMENT AND ATTITUDE. JOURNAL OF ADVANCED ENGLISH STUDIES, 3(2), 94-106.

Asrifan, A. (2021). ACADEMIC WRITING. LawArXiv. January, 2. https://doi.org/10.31228/osf.io/x2s7e

Asrifan, A. (2020). TUTORIAL PENGGUNAAN QUIZIZZ (www. quizizz. com) PADA PEMBELAJARAN. https://doi.org/10.31219/osf.io/kqnza

Asrifan, A. (2021). Abd Ghofur.“. THE USE OF READING CIRCLES IN INCREASING STUDENTS SPEAKING ABILITY AT THE ELEVENTH GRADE SMK NEGERI, 1. https://doi.org/10.31219/osf.io/8vjxy

Asrifan, A. (2020). Pandemic, Humanity and Education. https://doi.org/10.31219/osf.io/q2gpk

Asrifan, A. (2021). USING CAT AND MOUSE GAME TO IMPROVE STUDENT'S SPEAKING ABILITY AT THE ELEVENTH GRADE OF MA YMPI RAPPANG. https://doi.org/10.31219/osf.io/phtvn

Asrifan, A., \& Ghofur, A. (2021). THE USE OF READING CIRCLES IN INCREASING STUDENTS SPEAKING ABILITY AT THE ELEVENTH GRADE SMK NEGERI 1 PANCARIJANG. https://doi.org/10.31219/osf.io/8vjxy

Asrifan, A. (2021). Book Review: Halliday. 1989. Spoken and Written Language. Oxford University Press. https://doi.org/10.31219/osf.io/ej8tb

Asrifan, A., \& Ghofur, A. (2021). TALK, ACTION, SILENCE, INTERRUPTION AND THEIR IMPLICATIONS IN BUGINESE SOCIETY (SOPPENG REGENCY). https://doi.org/10.31219/osf.io/pv3ku

Asrifan, A. (2020). PENILAIAN BERBASIS ANDROID MENGGUNAKAN APLIKASI PLICKERS. https://doi.org/10.31219/osf.io/htreq

Haulussy, R. H., Najamuddin, I. R., \& Agustang, A. D. M. P. (2020). The sustainability of the Sasi Lola tradition and customary law (Case study in Masawoy Maluku, Indonesia). Intl J Sci Technol Res, 9(2), 5193-5195.

Arwan, A., Agustang, A., Arlin, A., Yani, A., \& PUTRA, D. M. (2019). Contestation of Elite Discourse in Treatment of HIV and AIDS. Iranian Journal of Public Health, 48(12), 2205.

Mutiara, I. A., Agustang, A., Adam, A., Upe, A., \& Equatora, M. A. (2020). The dynamics of prostitutes lives in metropolitan cities. Journal of Critical Reviews. https://doi. org/10.31838/jcr, 7, 165.

Usman, A., Agustang, A., Djalal, D., \& Annas, S. (2018, October). The Contribution Of Supporter Community In Maximizing Their Role For The Advancement Of Makassar Football Club (PSM). In 1st International Conference on Social Sciences (ICSS 2018). Atlantis Press.

Ma'na, P., Agustang, A., Salusu, J., Ikhsan, A., \& Dirawan, G. D. (2015). Decision making strategic value based local wisdom Tongkonan North Toraja. Man India, 95(3), 633-639.

Dirawan, G. D. FOSTERING COLLABORATION STREET CHILDREN IN MAKASSAR. Man In India, 95(3), 569-576.

Abdurachman, A. D. M. P. A., \& Agustang, A. Culture Of Shame-Heart And Social Solidarity Of Kaitetu People Central Maluku District, Indonesia.

Aida, K. N., Agustang, A., Arlin, A., \& Agustang, A. D. M. The Patron-Client Relationship Patterns In Siwa Lima Fishermen Community, Aru Islands District Maluku, Indonesia.

Pannyiwi, R., Agustang, A., Kasnawi, T., Pada, A. T., Yani, A., \& Syam, S. (2020). Social Network for Drug Circulation in Sidenreng Rappang Regency, Indonesia. Systematic Reviews in Pharmacy, 11(9), 575-577.

Upe, A., Salman, D., \& Agustang, A. (2019). The effects of the exploitation of natural resources towards risk society construction in Southeast Sulawesi Province, Indonesia. Journal of Degraded and Mining Lands Management, 6(2), 1587.

Matakena, F., Watloly, A., Agustang, A., Adam, A., \& Alim, A. (2020). The Self-Concept of Ale Rasa Beta Rasa in the Orang Basudara Community in Ambon (Studies on the Community of Passo and Batumerah Country). International Journal, 9, 1307.

Asmi, A. S., Kasnawi, M. T., Agustang, A., \& Yani, A. (2020). Sociocultural Transformation in Efforts to Reduce Mortality of Infants in Bone Regency, Indonesia. Systematic Reviews in Pharmacy, 11(10), 762-765.

Usmana, A., \& Agustangb, A. The Implementation of “Arif” Social Behaviour within Perssin Supporters in Sinjai District.

Hasan, I. R., Agustang, A., Kahar, F., \& Tahir, H. (2019). Super Service Delivery": an advanced conceptual model of onestop service for wide administrative region. Problems and perspectives in management, (17, Iss. 1), 189-201.

Asrifan, A. (2021). ISSUES IN TEFL “International Article Summary \& Presentation”: Students' Reactions to School Based Oral Assessment: Bridging the Gap in Malaysia. https://doi.org/10.31228/osf.io/te3m5

Asrifan, A., Al Yakin, A., \& Sahabuddin, C. The Use of Dictogloss Technique on ELT Classroom: An Experiment Study of Students Listening Comprehension.

Octaberlina, L. R., \& Asrifan, A. (2021). THE USE OF HUMOR STORY IN IMPROVING THE STUDENTS'READING COMPREHENSION. https://doi.org/10.31219/osf.io/kvsbe

Octaberlina, L. R., \& Asrifan, A. (2021). THE TEXT-BASED CHARACTER IN TEACHING READING COMPREHENSION AT THE TENTH GRADE STUDENTS. https://doi.org/10.31219/osf.io/p53sn

Asrifan, A. (2021). CODE MIXING AND CODE SWITCHING IN THE EFL CLASSROOM INTERACTION. https://doi.org/10.31228/osf.io/xd45c

Asrifan, A. (2021). ADVANCED GRAMMAR “Adverbs and Adverb Clauses”. https://doi.org/10.31228/osf.io/cuh83

Asrifan, A. (2020). TUTORIAL PENGGUNAAN QUIZIZZ (www. quizizz. com) PADA PEMBELAJARAN. 
https://doi.org/10.31219/osf.io/kqnza

Asrifan, A., \& Aeni, N. Book Review: I SPEAK FIVE LANGUAGES: FOSTERING PLURILINGUAL COMPETENCE THROUGH LANGUAGE AWARENESS By: Oliveira and Helena, Maria. https://doi.org/10.31228/osf.io/tjnq9

Asrifan, A. (2021). Modul Perkuliahan RESEARCH ON ENGLISH LANGUAGE TEACHING. https://doi.org/10.31219/osf.io/5rgvc

Asrifan, A. (2021). IMPROVING STUDENTS'SPEAKING ABILITY BY USING HAND DOLLS OF THE ELEVENTH GRADE STUDENTS OF MA YMPI RAPPANG. https://doi.org/10.31219/osf.io/zfhqu

Asrifan, A., Octaberlina, L. R., \& Handayani, R. (2021). SEMANTIC ANALYSIS ON THE USE OF ENGLISH LANGUAGE SLOGAN. https://doi.org/10.35542/osf.io/vtx5y

Asrifan, A. (2021). Book Review KONSTRUKSI GROUNDED TEORI Petunjuk Praktis Dalam Analisa Kualitatif Written By: Kathy Charmez. https://doi.org/10.31228/osf.io/nt8yk

Qisti, N., Nurwidah, A., Muslimin, I., \& Asrifan, A. (2020). THE EFFECT OF TEMPERATURE AND TIME DRYING TOWARD ORGANOLEPTIC QUALITY OF THE DUCKS BONE MEAL. Solid State Technology, 63(6), 1965219659.

Asrifan, A., \& Ghofur, A. Book Review: Writing for Academic Journals Second Edition. https://doi.org/10.31219/osf.io/su3ya

Andi Asrifan, N. (2020). THE TEXT-BASED CHARACTER IN TEACHING READING COMPREHENSION AT THE TENTH GRADE STUDENTS OF SMAN 4 SENRENG RAPPANG. Sarwah: Journal of Islamic Civilization and Thought, 18(02), 33-51.

Octaberlina, L. R., \& Asrifan, A. (2021). THE USE OF HUMOR STORY IN IMPROVING THE STUDENTS'READING COMPREHENSION.

Agustang, A., Mutiara, I. A., \& Asrifan, A. (2021). Genealogi Stigma Sosial Terhadap Pasien Covid 19. https://doi.org/10.31219/osf.io/ep7jf

Agustang, A., Ahriani, A., \& Asrifan, A. (2021). MARGINALISASI BUDAYA (STUDI PADA PRANATA SOSIAL MASYARAKAT MUSLIM SUKU KOKODA KOTA SORONG). https://doi.org/10.31219/osf.io/942y8

Agustang, A., Ariani, A. I., \& Asrifan, A. (2021). KONSTRUKSI SOSIAL JANDA TEREKSPLOITASI (STUDI KASUS DI KELURAHAN TETEBATU KECAMATAN PALLANGGA KABUPATEN GOWA).

Asrifan, A. (2021). APLIKASI DAN IMPLIKASI BERPIKIR SISTEMIK (SYSTEMIC THINKING) DALAM KEHIDUPAN.

Asrifan, A. (2021). PSIKOLOGI BELAJAR/TEORI BELAJAR: IMPLIKASI DAN HARAPAN.

Asrifan, A. (2021). PENDALAMAN MATA KULIAH SOCIOLINGUISTICS VARIASI SOSIAL PENGGUNA BAHASA.

Agustang, A. (2021). INTERAKSI SOSIAL KOMUNITAS LOKAL DENGAN PENDATANG DAN PERUBAHAN STRUKTUR KOMUNITAS LOKAL (Studi pada Masyarakat Majemuk di Kawasan Industri Makassar).

Agustang, A. (2021). KESEJAHTERAAN PSIKOLOGIS (studi Pada Dewasa Madya Yang Belum Menikah Di Kota Makassar).

Amelia, S., Lubis, N. D. A., \& Balatif, R. (2020). MIKROORGANISME DAN BAHAN PANGAN. Penerbit Qiara Media

Amelia, S., Lubis, N. D. A., Siregar, M. A., \& Rozi, M. F. (2018). Research Article Antimicrobial Effect of Wasabia japonica or Wasabi on Raw Salmon in Served Sashimi at Japanese Restaurants in Medan.

Nasution, I. K., Lubis, N. D. A., Erwin, I., \& Nusa, M. I. (2018). Cognitive Function Differences based on Hemispheric Lesions of First-Ever Ischemic Stroke Patients. Ethnicity, 31, 44-30.

Lubis, N. D. A., Amelia, S., \& Balatif, R. (2020). Microbial Content Test on Sliced Papaya in Area of Universitas Sumatera Utara. Journal of Saintech Transfer, 3(2), 86-92.

Lubis, N. D. A., \& Sari, M. I. (2016, December). Body Mass Index and Triglyceride Levels of the Students of Faculty of Medicine University of North Sumatra 2016. In 1st Public Health International Conference (PHICo 2016). Atlantis Press.

Lubis, N. D. A., \& Lubis, H. A. P. (2016). Korelasi Indeks Massa Tubuh dengan Kebugaran Kardiorespirasi pada Siswa SMA Sutomo 2 Medan.

Lubis, N. D. A., Panggabean, M., \& Ichwan, M. (2020, November). Penguatan Sumberdaya Keluarga Dalam Mempercepat Perbaikan Gizi Masyarakat. In Talenta Conference Series: Agricultural and Natural Resources (ANR) (Vol. 3, No. 2).

Nasution, I. K., Lubis, N. D. A., Amelia, S., \& Hocin, K. (2018, March). The correlation of pain intensity and quality of life in chronic LBP patients in Adam Malik general hospital. In IOP Conference Series: Earth and Environmental Science (Vol. 125, No. 1, p. 012183). IOP Publishing.

Kusnadi, J. (2018). Pengawet Alami untuk Makanan. Universitas Brawijaya Press.

Amelia, S., Lubis, N. D. A., Balatif, R., Rozi, M. F., \& Sidhi, S. P. (2020, January). Antibacterial effect of Andaliman (Zanthoxylum acanthopodium) against contaminant in raw common carp (Cyprinus carpio Linnaeus). In IOP Conference Series: Earth and Environmental Science (Vol. 425, No. 1, p. 012036). IOP Publishing.

Amelia, S., Lubis, N. D. A., Rozi, M. F., \& Nababan, I. F. F. (2018, November). Safe processing method and storage time threshold for consuming of powdered-infant formula based on total plate count test. In IOP Conference Series: Earth and Environmental Science (Vol. 205, No. 1, p. 012033). IOP Publishing.

Amelia, S., Lubis, N. D. A., Siregar, M. A., \& Rozi, M. F. (2018). Research Article Antimicrobial Effect of Wasabia japonica or Wasabi on Raw Salmon in Served Sashimi at Japanese Restaurants in Medan

Rosli, M. H. (2018). Korelasi Antara Status Gizi dan Status Anemia Terhadap Indeks Prestasi (IP) Mahasiswa Malaysia yang Studi di Universitas Sumatera Utara.

Lubis, N. D. A., \& Sari, M. I. (2016, December). Body Mass Index and Triglyceride Levels of the Students of Faculty of Medicine University of North Sumatra 2016. In 1st Public Health International Conference (PHICo 2016). Atlantis 
Press.

Lubis, N. D. A., Nasution, T. A., Wahyuni, D. D., \& Feriyawati, L. (2020, November). Gambaran Umum Status Kesehatan Siswa SDN 040494 Susuk Kecamatan Tiganderket, Kabupaten Karo. In Talenta Conference Series: Agricultural and Natural Resources (ANR) (Vol. 3, No. 2).

Lubis, N. D. A., Amelia, S., \& Balatif, R. (2020). Microbial Content Test on Sliced Papaya in Area of Universitas Sumatera Utara. Journal of Saintech Transfer, 3(2), 86-92.

LUBIS, N. D. A., NASUTION, T. A., \& PERMALU, R. K. LACK OF NUTRITION PROBLEM AMONG PRIMARY SCHOOL PUPILS IN MEDAN MUNICIPALITY.

Amelia, S., Lubis, N. D. A., \& Balatif, R. (2020). Coliform Quality Test on Tofu Samples in Three Markets in Medan City. Systematic Reviews in Pharmacy, 11(5), 619-623.

Yusraini, E., \& Lubis, N. D. A. (2020). Partial properties of young corn flour based on particle size and its effect on texture and sensory acceptability of biscuit. E\&ES, 454(1), 012117.

Amelia, S., Lubis, N. D. A., Balatif, R., Rozi, M. F., \& Sidhi, S. P. (2020, January). Antibacterial effect of Andaliman (Zanthoxylum acanthopodium) against contaminant in raw common carp (Cyprinus carpio Linnaeus). In IOP Conference Series: Earth and Environmental Science (Vol. 425, No. 1, p. 012036). IOP Publishing.

Amelia, S., Lubis, N. D. A., Rozi, M. F., \& Nababan, I. F. F. (2018, November). Safe processing method and storage time threshold for consuming of powdered-infant formula based on total plate count test. In IOP Conference Series: Earth and Environmental Science (Vol. 205, No. 1, p. 012033). IOP Publishing.

Nasution, I. K., Lubis, N. D. A., Erwin, I., \& Nusa, M. I. (2018). Cognitive Function Differences based on Hemispheric Lesions of First-Ever Ischemic Stroke Patients. Ethnicity, 31, 44-30. 